\title{
ADHESION OF FIMBRIATE ESCHERICHIA COLI TO BOVINE MAMMARY-GLAND EPITHELIAL CELLS \\ IN VITRO
}

\author{
Margaret Harper, A. Turvey and A. J. Bramley* \\ National Institute for Research in Dairying, Shinfield, Reading, Berks RG2 9AT
}

Plate VI

THE possible significance of bacterial attachment to epithelial cell surfaces as an initial stage in the establishment of infection has attracted increasing attention in recent years. The K88 and K99 surface antigens of Escherichia coli have been found to mediate specific attachment of the organism to brushborder cells of the piglet (Jones and Rutter, 1972) and calf (Burrows, Sellwood and Gibbons, 1976). Furthermore, the role of fimbriae (pili) in epithelial-cell binding of group-A streptococci (Beachey and Ofek, 1976) and gonococci (Ward and Watt, 1972; Swanson, 1973) has been studied.

It has been postulated that the ability of a micro-organism to attach to bovine mammary-gland epithelium might be of significance in the pathogenesis of mammary infections of the lactating dairy cow, in which bacteria have to withstand flushing out during milking (Reiter and Bramley, 1975). Frost (1975) and Frost, Wanasinghe and Woolcock (1977) reported that Streptococcus agalactiae and Staphylococcus aureus could adhere to isolated ductular cells whilst $E$. coli could not. In addition, no evidence of adhesion was found when K88-positive and -negative strains of $E$. coli were used to infect the mammary glands of the mouse and the cow (Anderson, Burrows and Bramley, 1977). However, it was known that most mastitis isolates of $E$. coli were at least genotypically fimbriate and that fimbriae could mediate attachment of E. coli and Salmonella and Shigella spp. to epithelial cells (Duguid and Gillies, 1957; Ofek, Mirelman and Sharon, 1977). Furthermore it has been reported that a fimbriate strain of Salmonella typhimurium infected mice more readily by the oral route than did a non-fimbriate mutant of the same strain (Duguid, Darekar and Wheater, 1976).

The present paper reports investigations on the role of fimbriae in the adhesion of $E$. coli to mammary-gland epithelial cells in vitro. An in-vitro test of adhesion to cryostat-prepared tissue sections is described.

\section{MATERIALS AND METHODS \\ Organisms}

E. coli strain P4 (O32 : K ?-NCDO 2070) was isolated from a clinical case of mastitis and shown to be virulent for the lactating cow (Bramley, 1976); fimbriae were demonstrated by

Received 27 July 1977; accepted 5 Sept. 1977.

J. MED. MICROBIOL.-VOL. 11 (1978) 
electronmicroscopy and by the ability of the organism to produce mannose-sensitive haemagglutination of a freshly prepared suspension of red blood cells $(3 \%)$ from guinea-pigs (GPRBC). The strain retains fimbriae even when subcultured on agar.

$E$. coli strain E4 $(086: \mathrm{K} 61: \mathrm{H} 8)$ was isolated from a human patient with infantile enteritis and produces fimbriae only when subcultured serially in broth. It is sensitive to the bactericidal activity of normal bovine serum and is avirulent for the lactating udder.

\section{Growth of bacteria for the adhesion test}

Organisms were maintained on nutrient agar (NA) slopes at $4^{\circ} \mathrm{C}$ and were also subcultured daily in trypticase soy broth (TSB) to enhance their production of fimbriae. Test organisms were subcultured in $5 \mathrm{ml}$ of Lemco Broth (LB), the inoculum being taken either from a NA slope or TSB culture, depending upon the state of fimbriation required. The LB culture was incubated for $16-18 \mathrm{~h}$ at $37^{\circ} \mathrm{C}$; the organisms were then washed three times in $0.01 \mathrm{M}$ phosphate-buffered saline (PBS) and diluted 1 in 10 in PBS. This diluted suspension contained approximately $10^{8}$ colony-forming units (c.f.u.) per ml (range $0.4 \times 10^{8}$ to $2.0 \times 10^{8}$ ) and was used in the adhesion test.

\section{Preparation of epithelial cell suspensions}

Barren, lactating cows from the Institute herd, known to be free from mammary infection, were used. After the animals were killed, the teats were thoroughly cleaned and then removed, bearing with them a portion of the lactiferous sinus and lower mammary gland. This tissue was kept on ice and transported to the laboratory where the teat exterior was cleaned with $70 \%$ ethanol and the teat and lactiferous sinus were separated. The teat sinus (TS), lactiferous sinus (LS) and larger lactiferous ducts were exposed by dissection and washed with $75-100 \mathrm{ml}$ of sterile PBS. The cells from the three areas of epithelium were then gently detached by means of a test-tube brush and suspended in $5 \mathrm{ml}$ of PBS. Cells from the TS and LS were washed twice in PBS at $4^{\circ} \mathrm{C}$ and in most experiments the suspensions from the quarters of the udder were pooled to give a bulk teat- or lactiferous-sinus cell suspension. In the later experiments the teat- and lactiferous-sinus cell suspensions were bulked to give a single suspension. These suspensions were used in the test described below and they contained approximately $10^{6}$ cells per $\mathrm{ml}$ (range $0.5 \times 10^{6}$ to $5 \times 10^{6}$ ).

\section{In-vitro adhesion test methods}

Suspension test. Equal volumes $(1$ or $2 \mathrm{ml})$ of bacterial and epithelial-cell suspensions were mixed and incubated at $37^{\circ} \mathrm{C}$ for $1 \mathrm{~h}$ on a roller rotating at 45 r.p.m. The samples were then washed three times with PBS at $4^{\circ} \mathrm{C}$, slow centrifugation $(120 \mathrm{~g})$ being used to minimise cell damage and improve the separation of bacteria and epithelial cells. After the final wash, the samples were resuspended in PBS to half the original volume and $0.01-\mathrm{ml}$ amounts were spread in duplicate over $1-\mathrm{cm}^{2}$ areas etched on glass slides. The films were air-dried, fixed with methanol and stained with polychrome methylene blue for $5 \mathrm{~min}$. The numbers of epithelial cells per $\mathrm{ml}$ of the initial suspension, the numbers of bacteria adhering to 50 or 100 cells, and the percentage of cells showing adherent bacteria were measured. Fields were counted over the film at random except that thick clumps of cells were avoided. In each test a control suspension with no added bacteria was examined to ensure that no contaminating bacteria were visible.

Slide test. Teat sinus tissue was removed from killed lactating cows of the Institute herd and suitably-sized pieces were snap frozen in isopentane cooled with liquid nitrogen. Thick cryostat sections $(6 \mu \mathrm{m})$ were cut and picked off the knife with a glass slide at room temperature. The section-bearing slides were stored at $4{ }^{\circ} \mathrm{C}$ until required.

In the adhesion test, $20 \mathrm{ml}$ of a washed suspension of $E$. coli in PBS (approximately $10^{9}$ c.f.u. per $\mathrm{ml}$ ) and a section-bearing slide were placed in a rotating plastic container and incubated at $37^{\circ} \mathrm{C}$ for $1 \mathrm{~h}$ at 45 r.p.m. The slide was then removed, rinsed thoroughly with PBS and fixed in $10 \%$ formalin in ethyl alcohol. Sections were stained with polychrome methylene blue for $5 \mathrm{~min}$. and then dehydrated and mounted. A control slide incubated with sterile PBS was similarly processed. 
Measurement of haemagglutinating (HA) activity of E. coli. A second 5-ml LB culture was incubated in parallel with the adhesion test culture at $37^{\circ} \mathrm{C}$ for $16-18 \mathrm{~h}$. The cultures were centrifuged and the supernates discarded, leaving a small volume $(<0.5 \mathrm{ml})$ in which the deposit was resuspended. These suspensions were then tested for their ability to produce mannosesensitive haemagglutination of a 3\% suspension of GPRBC (Duguid and Gillies, 1957).

Relative HA potencies were measured by resuspending the bacterial pellet in $0.5 \mathrm{ml}$ of sterile $0 \cdot 85 \%$ saline and preparing doubling dilutions up to 1 in 64 . These were tested for their ability to haemagglutinate GPRBC suspension. The viable count of the bacterial suspersion and the optical density at $650 \mathrm{~nm}$ of a 10 -fold dilution in saline were measured.

\section{RESULTS}

Tests of adhesion of fimbriate and non-fimbriate Escherichia coli to mammary-gland epithelial cells in vitro

Adhesion tests were done in duplicate and a fresh cell suspension from a different cow was used for each. The numbers of bacteria adhering to the cells and the perceritage of cells showing adherent bacteria are detailed in table 1 .

A non-fimbriate suspension of strain E4 grown in LB seeded from a NA slope showed no HA activity for GPRBC and adhered poorly to the epithelial cells (fig. 1). Fimbriate suspensions of strains E4 and P4 grown from brothculture inocula showed mannose-sensitive haemagglutination of GPRBC and striking adhesion to the epithelial cells (fig. 2). The variation in degree of adhesion detected in the first and second tests with strain E4 probably reflects differences in the state of fimbriation of the cultures used. The results obtained with the teat and lactiferous-sinus cell suspensions were similar.

\section{Relationship between adhesion to epithelial cells and the degree of fimbriation}

Seven broth cultures of $E$. coli strain E4 were prepared in such a manner that, at the time of testing, they had been subcultured daily in LB for $1,2,5,8,11,14$

TABLE I

Adhesion of Escherichia coli strain P4 and fimbriate and non-fimbriate cultures of E. coli strain E4 to mammary-gland epithelial cells in vitro

\begin{tabular}{|c|c|c|c|c|c|c|c|c|}
\hline \multirow[t]{2}{*}{$\begin{array}{l}\text { Strain and } \\
\text { fimbrial state }\end{array}$} & \multirow{2}{*}{$\begin{array}{c}\text { Haemag- } \\
\text { glutination } \\
\text { of } 3 \% \\
\text { GPRBC }\end{array}$} & \multirow{2}{*}{$\begin{array}{c}\text { Viable count } \\
\text { of organisms } \\
\text { (as } 10^{8} \\
\text { c.f.u.) per } \\
\text { ml } \\
\text { suspension }\end{array}$} & \multicolumn{2}{|c|}{$\begin{array}{l}\text { Number of } \\
\text { epithelial cells } \\
\left(10^{6}\right) \text { per ml of }\end{array}$} & \multicolumn{2}{|c|}{$\begin{array}{l}\text { Number of } E \text {. coli } \\
\text { adhering to } 50 \text { cells } \\
\text { in }\end{array}$} & \multicolumn{2}{|c|}{$\begin{array}{l}\text { Percentage of } 50 \\
\text { cells in the stated } \\
\text { suspension showing } \\
\text { adherent } E \text {. coli }\end{array}$} \\
\hline & & & TS & LS & TS & LS & TS & LS \\
\hline $\begin{array}{l}\text { E. coli } \mathrm{P} 4 \\
\text { (fimbriate) }\end{array}$ & + & $\begin{array}{l}0 \cdot 78 \\
1 \cdot 2\end{array}$ & $\begin{array}{l}0.72 \\
0.56\end{array}$ & $\begin{array}{l}0.95 \\
1 \cdot 2\end{array}$ & $\begin{array}{l}466 \\
336\end{array}$ & $\begin{array}{l}408 \\
227\end{array}$ & $\begin{array}{l}82 \\
76\end{array}$ & $\begin{array}{l}78 \\
68\end{array}$ \\
\hline $\begin{array}{l}\text { E. coli } \mathrm{E} 4 \\
\text { (fimbriate) }\end{array}$ & $\begin{array}{l}+ \\
+\end{array}$ & $\begin{array}{l}0.91 \\
1.2\end{array}$ & $\begin{array}{l}0.72 \\
0.56\end{array}$ & $\begin{array}{l}0.95 \\
1.2\end{array}$ & $\begin{array}{r}96 \\
425\end{array}$ & $\begin{array}{l}179 \\
491\end{array}$ & $\begin{array}{l}50 \\
84\end{array}$ & $\begin{array}{l}62 \\
84\end{array}$ \\
\hline $\begin{array}{l}\text { E. coli E4 } \\
\text { (non-fimbriate) }\end{array}$ & $\overline{-}$ & $\begin{array}{l}0.52 \\
0.77\end{array}$ & $\begin{array}{l}0.72 \\
0.56\end{array}$ & $\begin{array}{l}0.95 \\
1 \cdot 2\end{array}$ & $\begin{array}{r}33 \\
9\end{array}$ & $\begin{array}{r}11 \\
8\end{array}$ & $\begin{array}{l}38 \\
14\end{array}$ & $\begin{array}{l}14 \\
10\end{array}$ \\
\hline
\end{tabular}

GPRBC $=\mathrm{A} 3 \%$ suspension of guinea-pig red blood cells; TS = teat-sinus cell suspension; LS = lactiferous-sinus cell suspension. 
or 17 successive days to produce cultures with graded degrees of fimbriation. The ability of suspensions prepared from these cultures to haemagglutinate GPRBC and to adhere to pooled teat- and lactiferous-sinus cell suspensions was then measured.

Details of growth and HA activity, and the adhesion test result may be seen in table II.

An increase in HA activity was associated with higher viable counts and an increase in optical density of the suspensions. The consequence of this was that the ratio of $E$. coli organisms to epithelial cells in the test mixtures increased with increasing HA activity. To counteract this bias, the haemagglutination titre has been related either to the viable count (coefficient 1) or to the optical density (coefficient 2). With either method of assessment, an increasing trend in HA activity was associated with an increase both in the numbers of $E$. coli adhering to 100 cells and in the percentage of cells showing adherent bacteria.

\section{The effect of $2 \%$ D-mannose, skim and whole milk on the adhesion of fimbriate E. coli to epithelial cells}

The ability of fimbriate organisms of $E$. coli strain $\mathrm{P} 4$ to adhere to isolated epithelial cells (pooled from the teat and lactiferous sinuses) was measured when the cells were incubated in (i) PBS, (ii) PBS $+2 \%$ D-mannose, (iii) sterile skim milk, or (iv) aseptically-collected whole milk with a total bacterial count of $<10$ per ml, and a coli-aerogenes count of $<1$ per ml. After incubation the routine washing procedure with PBS was used.

The adhesion data are given in table III. Skim milk and PBS suspensions gave similar adhesion values. Striking reductions in the numbers of adherent $E$. coli were detected when either $2 \% \mathrm{D}$-mannose in PBS or whole milk was used as the suspending medium $(11.5 \%$ and $48.5 \%$ of the PBS values respectively).

TABLE II

Haemagglutinating $(H A)$ activity for guinea-pig erythrocytes and adhesion to mammarygland epithelial cells of bacterial suspensions prepared from broth cultures of Escherichia coli strain E4 after daily subculture for different periods

\begin{tabular}{|c|c|c|c|c|c|c|c|}
\hline \multirow{2}{*}{$\begin{array}{l}\text { Period of days } \\
\text { during which } \\
E . \text { coli } E 4 \text { had } \\
\text { undergone daily } \\
\text { subculture in } \\
\text { broth }\end{array}$} & \multirow{2}{*}{$\begin{array}{l}\text { (a) } \\
\text { Viable count } \\
\text { of organisms } \\
\text { (as } 109 \text { c.f.u.) } \\
\text { per ml of HA } \\
\text { suspension }\end{array}$} & \multirow{2}{*}{$\begin{array}{l}(b) \\
\text { Optical density } \\
\text { at } 650 \mathrm{~nm} \text { of } \\
1 \text { in } 10 \text { dilution } \\
\text { of HA suspension }\end{array}$} & \multirow{2}{*}{$\begin{array}{l}(c) \\
\text { Haemag- } \\
\text { glutina- } \\
\text { tion } \\
\text { titre }\end{array}$} & \multicolumn{2}{|c|}{$\begin{array}{l}\text { Haemagglutina- } \\
\text { tion coefficient }\end{array}$} & \multirow{2}{*}{$\begin{array}{l}\text { Number of } \\
E \text {. coli* } \\
\text { adhering to } \\
100 \text { cells }\end{array}$} & \multirow{2}{*}{$\begin{array}{l}\text { Percentage } \\
\text { of cells } \\
\text { showing } \\
\text { adherent } \\
E \text {. coli }\end{array}$} \\
\hline & & & & $\left.{ }^{1}\right)^{1}:(a)$ & $\stackrel{2}{2}{ }^{\prime}(b)$ & & \\
\hline $\begin{array}{r}1 \\
2 \\
5 \\
8 \\
11 \\
14 \\
17\end{array}$ & $\begin{array}{r}4.5 \\
2.5 \\
6.5 \\
7.0 \\
6.5 \\
7.5 \\
13.5\end{array}$ & $\begin{array}{l}0.75 \\
0.65 \\
0.90 \\
0.90 \\
1.0 \\
1.0 \\
1.1\end{array}$ & $\begin{array}{c}\ldots \\
\cdots \\
8 \\
4 \dagger \\
8 \dagger \\
8 \dagger \\
16 \dagger\end{array}$ & $\begin{array}{c}\ldots \\
\ldots .23 \\
1.23 \\
0.57 \\
1.23 \\
1.07 \\
1.28\end{array}$ & $\begin{array}{c}\ldots \\
\ldots .9 \\
8.9 \\
4 \cdot 45 \\
8.0 \\
8.0 \\
14.5\end{array}$ & $\begin{array}{r}19 \\
40 \\
455 \\
211 \\
415 \\
594 \\
982\end{array}$ & $\begin{array}{l}15 \\
26 \\
76 \\
47 \\
68 \\
85 \\
78\end{array}$ \\
\hline
\end{tabular}

* Range of viable $E$. coli per $\mathrm{ml}$ in adhesion test suspensions was $0.7 \times 10^{8}$ to $1.4 \times 10^{8}$ c.f.u. per $\mathrm{ml}$.

$\dagger$ Trace reaction at next doubling solution. 


\section{ADHESION OF FIMBRIATE ESCHERICHIA COLI}

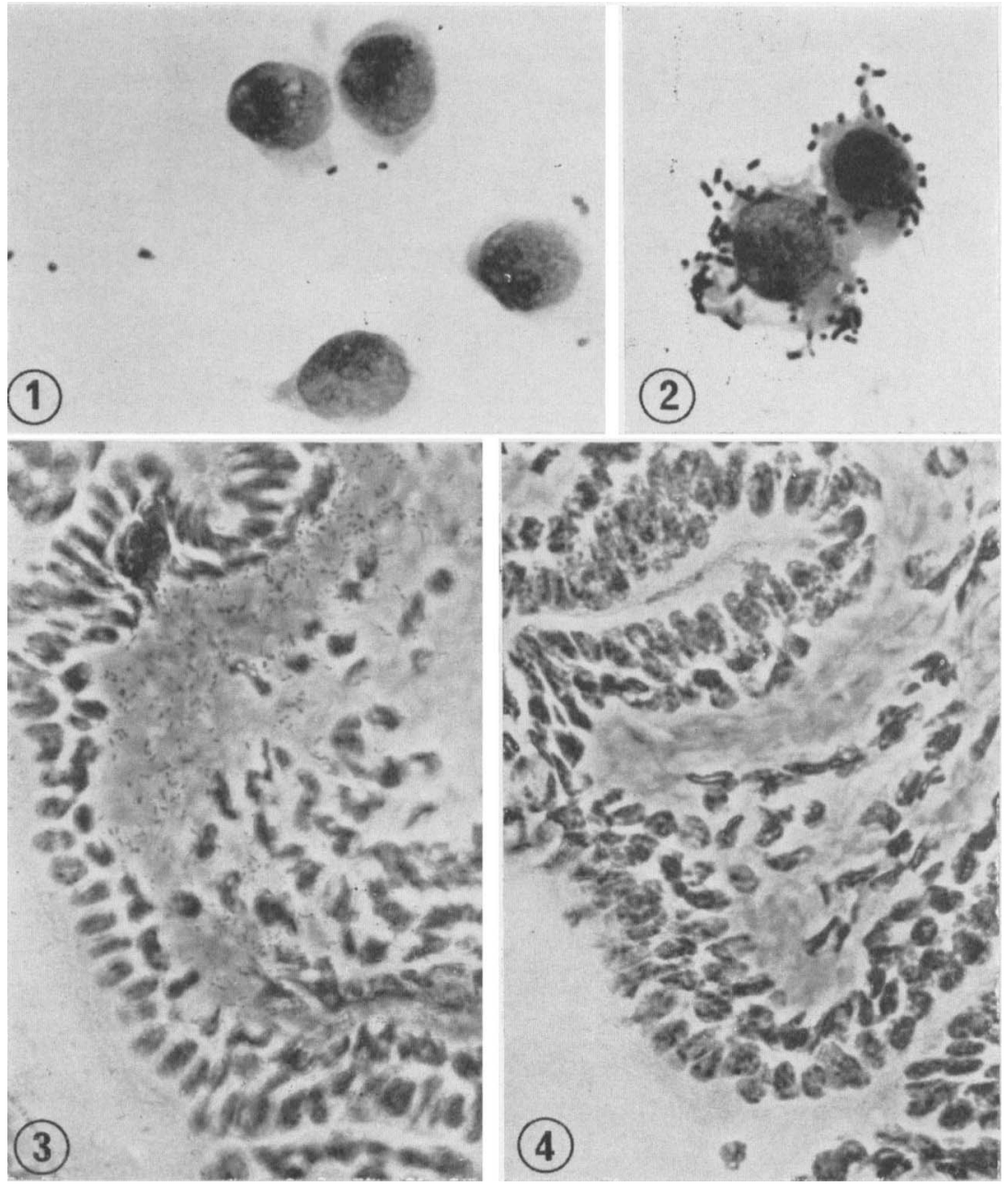

FIG. 1.-Epithelial cells after incubation with non-fimbriate Escherichia coli strain E4. Polychrome methylene blue $(\mathrm{MB}) . \times 1300$.

FIG. 2.-Epithelial cells showing adherent bacteria after incubation with fimbriate Escherichia coli strain E4. MB. $\times 1300$.

FIG. 3.-Section of teat sinus wall showing adherent bacteria after incubation with fimbriate Escherichia coli strain P4. MB. $\times 500$.

FIG. 4.-Section of teat sinus wall after incubation with non-fimbriate Escherichia coli strain E4. MB. $\times 500$. 
TABLE III

Effect of $2 \%$ D-mannose, skim and whole milk on the adhesion of E. coli P4 to mammary-gland epithelial cells*

\begin{tabular}{l|cc}
\multicolumn{1}{c|}{$\begin{array}{c}\text { Suspending } \\
\text { medium }\end{array}$} & $\begin{array}{c}\text { Number of } E \text {. colit } \\
\text { adhering to } \\
100 \text { cells }\end{array}$ & $\begin{array}{c}\text { Percentage of } \\
\text { cells showing } \\
\text { adherent } E \text {. coli }\end{array}$ \\
\hline PBS & 398 & 75 \\
PBS+ & & \\
2\% D-mannose & 46 & 40 \\
$\begin{array}{l}\text { Skim milk } \\
\text { Whole milk }\end{array}$ & 370 & 66 \\
& 192 & 36 \\
\hline
\end{tabular}

* The test bacterial suspension contained $10^{8}$ c.f.u. per ml, and the test epithelial-cell suspension contained $2.4 \times 10^{6}$ cells per ml.

$\dagger$ Mean of three counts.

\section{Adhesion studies with sections of bovine teat-sinus tissue}

The attachment of fimbriate and non-fimbriate cultures of $E$. coli strain $\mathrm{E} 4$ and of fimbriate $E$. coli strain $\mathrm{P} 4$ was examined. Large numbers of adherent bacilli were found when fimbriate cultures of $E$. coli P4 and E4 were used, but few adherent organisms were found with a non-fimbriate culture of E.coli $\mathrm{E} 4$ (figs. 3 and 4). The adhesion seen was not specific for epithelial cells, and bacilli occurred in rather greater numbers on the subepithelial collagen layer. The numbers of adherent bacteria were greatly reduced when whole milk or $2 \% \mathrm{D}$-mannose was used as suspending medium.

\section{DISCUSSION}

These results contrast sharply with those previously reported by Frost (1975) who detected little or no adhesion of $E$. coli. He used $E$. coli isolated from faeces, but Frost et al. (1977) reported that they were unable to detect adhesion when E. coli strains associated with bovine mastitis were used. We used one such strain and one human strain of $E$. coli and found that both adhered to epithelial cells from the teat or lactiferous sinuses. Adhesion was associated with the ability of the organisms to agglutinate a suspension of guinea-pig erythrocytes. Haemagglutination and adhesion could be prevented by the addition of $2 \% \mathrm{D}$-mannose, and this indicated that both effects were mediated by bacterial fimbriae (Duguid and Gillies, 1957) and distinct from other haemagglutination mechanisms that may also be associated with adhesion of Gram-negative bacteria (Burrows et al. 1976; Jones, Abrams and Freter, 1976).

If the organisms used by Frost were phenotypically non-fimbriate, little or no adhesion would have been detected in his tests. Our observation that whole milk reduced adhesion in vitro is important and may indicate why adhesion of $E$. coli has not been demonstrated in vivo (Frost, 1975; Anderson et al. 1977). The mechanism of inhibition of $E$. coli adhesion in milk is unclear. As adhesion occurred readily in skim milk, the inhibition observed with whole 
milk is possibly attributable to the adhesion of $E$. coli to milk fat-globule membranes. It has been shown that milk fat can inhibit the haemagglutination of red blood cells by K88 and K99 adhesin (Reiter and Brown, 1976).

The use of sections of teat-sinus tissue allowed adherent and non-adherent $E$. coli suspensions to be distinguished, but it did not easily allow a quantitative assessment of adhesion. In the present study the adhesion observed was relatively non-selective in that bacteria were seen adhering to tissue over the whole section, particularly to collagen, and not solely to cells lining the sinus. On the other hand, the technique has been satisfactorily used to demonstrate the specific attachment of K88-positive strains of $E$. coli to porcine intestine (Turvey; unpublished).

These results indicate that care should be taken in relating results of invitro tests with isolated cells to pathogenic mechanisms in vivo; for example it is clear that suspending fluids such as PBS may allow non-physiological mechanisms to operate. Moreover the growth conditions for the organism may influence the outcome of the test; this was shown by the fimbrial E. coli model in the present study, the gonococcal model of Novotny et al. (1977) and the non-fimbrial attachment study of Jones et al. (1976) with Vibrio cholerae.

\section{SUMMARY}

The adhesion of a bovine and a human isolate of Escherichia coli to epithelial cells from the teat and lactiferous sinuses of the udder was examined. Adhesion was detected with bacterial suspensions that produced mannose-sensitive agglutination of guinea-pig red cells. Adhesion to epithelial cells could be inhibited by mannose and the degree of adhesion occurring with a suspension correlated with its haemagglutinating activity. This demonstrated that fimbriae were responsible for the adhesion. The observation that whole milk inhibited attachment of $E$. coli to cells in vitro indicates that such attachment may not occur in vivo in the lactating cow.

We thank Miss E. M. Hogben for her technical assistance and B. E. Brooker for his helpful advice and co-operation. The willingness of the staff of Alf Meade Ltd (Reading) to co-operate during the slaughter of animals is appreciated.

\section{REFERENCES}

Anderson, J. C., Burrows, M. R. ANd Bramley, A. J. 1977. Bacterial adherence in mastitis caused by Escherichia coli. Vet. Path., 14, 518.

BEACHEY, E. H. AND OFEK, I. 1976. Epithelial cell binding of group A streptococci by lipoteichoic acid on fimbriae denuded of M protein. J. exp. Med., 143, 759.

BramLEY, A. J. 1976. Variations in the susceptibility of lactating and non-lactating bovine udders to infection when infused with Escherichia coli. J. Dairy Res., 43, 205.

Burrows, M. R., Sellwood, R. and Gibbons, R. A. 1976. Haemagglutinating and adhesive properties associated with the $\mathrm{K} 99$ antigen of bovine strains of Escherichia coli. J. gen. Microbiol., 96, 269.

Duguid, J. P., Darekar, M. R. AND Wheater, D. W. F. 1976. Fimbriae and infectivity in Salmonella typhimurium. J. med. Microbiol., 9, 459.

Duguid, J. P. AND Gillies, R. R. 1957. Fimbriae and adhesive properties in dysentery bacilli. J. Path. Bact., 74, 397. 
Frost, A. J. 1975. Selective adhesion of microorganisms to the ductular epithelium of the bovine mammary gland. Infect. Immun., 12, 1154.

Frost, A. J., Wanasinghe, D. D. ANd Woolcock, J. B. 1977. Some factors affecting selective adherence of microorganisms in the bovine mammary gland. Infect. Immun., $15,245$.

Jones, G. W., Abrams, G. D. AND Freter, R. 1976. Adhesive properties of Vibrio cholerae: adhesion to isolated rabbit brush border membranes and haemagglutinating activity. Infect. Immun., 14, 232.

Jones, G. W. AND RUTTER, J. M. 1972. Role of the K88 antigen in the pathogenesis of neonatal diarrhoea caused by Escherichia coli in piglets. Infect. Immun., 6, 918.

Novotny, P., Short, J. A., Hughes, M., Miler, J. J., Syrett, C., Turner, W. H., Harris, J. R. W. AND MacLenNan, I. P. B. 1977. Studies on the mechanism of pathogenicity of Neisseria gonorrhoeae. J. med. Microbiol., $10,347$.

Ofek, I., Mirelman, D. and Sharon, N. 1977. Adherence of Escherichia coli to human mucosal cells mediated by mannose receptors. Nature, Lond., 265, 623.

Reiter, B. AND Bramley, A. J. 1975. Defence mechanisms of the udder and their relevance to mastitis control. In Proceedings of the IDF Seminar on Mastitis Control, Reading, England. IDF, Brussels.

REITER, B. AND BROWN, T. 1976. Inhibition of the haemagglutination of red blood cells by K88 and K99 adhesin using milk fat and fat globule membrane. Proc. Soc. gen. Microbiol., 3, 109.

Swanson, J. 1973. Studies on gonococcus infection. IV. Pili: their role in attachment of gonococci to tissue culture cells. J. exp. Med., 137, 571 .

WARD, M. E. AND WATT, P. J. 1972. Adherence of Neisseria gonorrhoeae to urethral mucosal cells: an electron microscopic study of human gonorrhea. J. infect. Dis., 126, 601. 